\title{
BEAN COPRODUCT AS SOURCE OF PROTEIN IN DAIRY COWS DIETS
}

\author{
COPRODUTO DO FEIJÃO COMO FONTE PROTEICA EM DIETAS PARA \\ VACAS LEITEIRAS
}

\section{Marinaldo Divino RIBEIRO ${ }^{1}$; Fernando de Paula LEONEL ${ }^{2}$; Raphael Pavesi ARAUJO ${ }^{3}$; Raphael dos Santos GOMES ${ }^{4}$; Leonardo Marmo MOREIRA ${ }^{2}$; Carlos Renato VIEGAS ${ }^{5}$}

1. Universidade Federal de Goiás; Departamento de Zootecnia; Goiânia, GO, Brazil. malldor@gmail.com;

2. Universidade Federal de São João Del Rei, Campus CTAN, Departamento de Zootecnia, São João Del Rei, MG, Brazil. fernandoleonel@ufsj.edu.br; 3. Instituto Federal de Ciência e Tecnologia do Tocantins, Campus Colinas do Tocantins, Colinas do Tocantins, TO, Brazil; 4. Universidade Estadual do Norte Fluminense Darcy Ribeiro, Programa de Pós-Graduação em Ciência Animal, Campos dos Goytacazes, RJ, Brazil; 5. Universidade Federal Rural do Rio de Janeiro, Programa de Pós-Graduação em Zootecnia, Seropédica, RJ, Brazil.

\begin{abstract}
The objective of this study was to evaluate the supplementation of dairy cows with different protein sources in relation to intake, digestibility, production and chemical composition of milk. For this, eight crossbred cows (Hostein x Gir) were used, distributed in two simultaneous latin squares $(4 \times 4)$. The treatments used were: bean coproduct, soybean meal, sunflower meal and cottonseed meal. Four variance-covariance structures were tested by means of the Akaike criterion corrected to determine the best fit to the data, and afterwards they were submitted to analysis of variance, and the means of the treatments were compared by the Tukey's test, at $5 \%$ probability. Only intakes of crude protein and crude fat were influenced by the treatments, for the digestibility, regardless of the evaluated nutrient, the soybean meal was the best treatment or was among the best, a behavior also observed for milk production. Thus, it was concluded that soybean meal is the best source of protein among the supplements used, and the bean coproduct stands out as a low-cost protein source but should not fully replace soybean meal, especially in animal categories of higher nutritional requirement.
\end{abstract}

KEYWORDS: Bean coproduct. Digestibility. Intake. Milk production.

\section{INTRODUCTION}

In search of lower production costs for products of animal origin, the rational use of all available food resources has been focused. In this way, several agroindustrial residues or by-products, when employed in a rational way, can contribute to the reduction of the cost of feeding the animals (CARVALHO JÚNIOR et al., 2010).

By-products and residues resulting from grain processing are a promising alternative to the reduction of feed costs of the dairy herd. The rational use of these products depends mainly on their nutritional characteristics (PEREIRA, 2000).

Protein is an expensive nutrient and thus is the goal of several studies aimed at increasing its efficiency of use through the strategic use or replacement of traditional foods by those with better cost / benefit.

The replacement of soybean meal by alternative protein sources without compromising the performance of the animal may be a viable alternative for reducing feed costs the dairy herd. However, the potential for incorporation of these ingredients into diets for ruminant animals requires caution, planning, technical / financial assessment and market opportunity study (PINA et al., 2006).
The bean coproduct is composed of damaged or broken beans during the processing that are discarded, in some situations, the coproduct of beans represents up to $4 \%$ of the total grains harvested.

Grains of beans have the composition of $222-274 \mathrm{~g}$ de crude protein, 161-258 of neutral detergent fiber, $1-3 \mathrm{~g}$ of lignin and $11-24 \mathrm{~g}$ of ether extract, per kilo of dry matter (SHARASIA et al., 2017). Goes et al. (2013) found that the addition of beans in the diet of cattle did not affect animal performance, dry matter intake and feed efficiency. However, the digestibility of dry matter, organic matter, crude protein, ether extract and total carbohydrates decreased with the inclusion of 26 percent of beans.

Nunes (1998) characterized the bean residue as a product of low palatability and digestibility that presented the following recommendations: inclusion of up to $15 \%$ in concentrates destined to cattle and of 20 to $25 \%$ for sheep in fattening, with no reports being reported indication for lactating cows. In this way the bean coproduct stands out as an alternative to supplementation.

The objective of this study was to evaluate the supplementation of dairy cows with different protein sources (bean coproduct, cottonseed meal, 
sunflower meal, soybean meal) in relation to the intake and digestibility of nutrients, and production and chemical composition of milk.

\section{MATERIAL AND METHODS}

The experiment was conducted in the city of São João Del Rei (MG-Brazil), whose geographical coordinates are $21^{\circ} 08^{\prime} 00^{\prime \prime} \mathrm{S}$ and $44^{\circ} 15^{\prime} 40^{\prime \prime} \mathrm{W}$ in an altitude of $898 \mathrm{~m}$. The area is located in a region where an Cwa climate (Köppen standards) predominates with an annual rainfall of $1468 \mathrm{~mm}$ and average annual temperature of $20.1^{\circ} \mathrm{C}$.

Eight crossbred cows (3/4 Holstein x 1/4 Gir) were used, with an average weight of $554.59 \pm$ $30.43 \mathrm{~kg}$, average production of $14.85 \pm 3.28 \mathrm{~kg}$ of milk / day and lactational period between 60 and 90 days of lactation. The animals were kept in pickets with Brachiaria brizanta cv. MG5, equipped with drinking fountains and salt shakers, in a rotational stocking system.

The cows were distributed in two simultaneous $4 \times 4$ latin square design. The experiment lasted 84 days, and each period had 21 days, with the first 14 days used for adaptation and the others for data collection. The treatments consisted of the protein source used to compose the concentrate supplement: coproduct bean, soybean meal, sunflower meal, cottonseed meal. concentrate supplement were formulated according to the production requirements of the animals and in accordance with the recommendations of the NRC (2001), the level of $22 \%$ of crude protein (CP) on a dry matter basis was established for the concentrates (Tables 1 and 2). The concentrate supplement was offered daily to animals after milking in the amount of five $\mathrm{kg}$.

The quantities of concentrate supplied and orts left by each animal were recorded to estimate the intake. At the moment of feeding, all through the experimental periods, the diets and orts were sampled. Samples of all ingredients used and all concentrates were also collected during the preparation of the mixtures, which were conditioned in plastic bags and frozen for subsequent analyses.

For the collection of the pasture samples, the simulated-grazing method proposed by Sollenbergger and Cherney (1995) was adopted. The samples were collected by the hand-plucking method, in which the forage is collected manually after previous observation of the grazing habit of the animals.
The samples were dried in a forcedventilation oven at $55^{\circ} \mathrm{C}$ for $72 \mathrm{~h}$, and the definitive dry matter was determined in an oven at $105^{\circ} \mathrm{C}$ (DM, method 967.03; AOAC, 1990). The crude protein (CP, method 2001.11; THIEX et al., 2002), crude fat (CF, method 2003.06; THIEX et al., 2003), and ashes (Ash; method 942.05; AOAC, 1990) were performed. The neutral detergent fiber (NDF) was evaluated according to the protocols suggested by Van Soest et al. (1991). Total carbohydrates (TC) was calculated according to Sniffen et al. (1992): TC $(\mathrm{g} / \mathrm{kg}$ as DM $)=1000-(\mathrm{CP}$ $+\mathrm{CF}+\mathrm{MM}$ ), whereas non-fibrous carbohydrate was calculated by: NFC $(\mathrm{g} / \mathrm{kg}$ as $\mathrm{DM})=1000-(\mathrm{CP}$ $+\mathrm{CF}+\mathrm{MM}+\mathrm{NDF}$ ).

To calculate the excreted fecal matter chromic oxide $\left(\mathrm{Cr}_{2} \mathrm{O}_{3}\right)$ was used as external marker. The marker was weighed $(10 \mathrm{~g})$, conditioned in filter paper and administered, via esophagus, in a single daily dose after the morning milking, during the ten days of experimental period (SILVA and LEÃO, 1979).

Feces were collected on the tenth, twelfth and fourteenth days of each experimental period, twice daily, at $08 \mathrm{~h} 00$ and $16 \mathrm{~h} 00$, directly from the rectum of the animals, according to the technique described by Leão (2002). Immediately after collection, the samples of feces were conditioned in plastic bags, labeled and frozen at $-10{ }^{\circ} \mathrm{C}$. Subsequently, the samples were composed on the basis of the air-dry weight, per treatment and period, and analyzed for the chromium content on an atomic absorption spectrophotometer, according to the method described by Williams et al. (1962).

For fecal output determination, the following formula was utilized $\mathrm{FO}=\mathrm{OF} / \mathrm{COF}$, where: $\mathrm{FO}=$ daily fecal output $\left(\mathrm{g} \mathrm{DM} \mathrm{day}^{-1}\right)$; $\mathrm{OF}=$ chromic oxide offered $\left(\mathrm{g} \mathrm{day}^{-1}\right)$; and COF $=$ concentration of the chromic oxide in the feces $\left(\mathrm{g} \mathrm{g}^{-1} \mathrm{DM}\right)$.

Indigestible neutral detergent fiber (iNDF) obtained after $144 \mathrm{~h}$ of incubation was used to determine the dry matter intake, in accordance with the technique adopted by Cochran et al. (1986). In this way, the ratio between the daily intake of the marker and its concentration in the feces was established. For the evaluation of the iNDF, the feeds and feces were ground in a $1 \mathrm{~mm}$ sieve mill and conditioned in non-woven textile (TNT 100) bags measuring $4 \times 5 \mathrm{~cm}$, following a ratio of $20 \mathrm{mg}$ of DM per square centimeter of surface (NOCEK, 1997). 
Table 1. Chemical composition of the feedstuffs used as inputs to optimize the treatment diets.

\begin{tabular}{|c|c|c|c|c|c|}
\hline \multirow{2}{*}{ Nutrient } & \multicolumn{4}{|l|}{ Treatment } & \multirow{2}{*}{ Pasture } \\
\hline & Bean coproduct & Soybean meal & Sunflower meal & Cottonseed meal & \\
\hline DM & 939.4 & 958.9 & 950.5 & 959.6 & 239.9 \\
\hline OM & 953.3 & 934.5 & 943.4 & 944.1 & 903.1 \\
\hline $\mathrm{CP}$ & 205.4 & 460.9 & 272.5 & 314.4 & 96.8 \\
\hline $\mathrm{NDF}$ & 184.0 & 234.5 & 454.7 & 217.9 & 609.2 \\
\hline $\mathrm{CF}$ & 13.2 & 9.3 & 23.1 & 13.9 & 15.8 \\
\hline Ash & 46.7 & 65.5 & 55.9 & 56.6 & 96.9 \\
\hline TC & 734.7 & 464.3 & 648.5 & 615.1 & 790.5 \\
\hline NFC & 575.9 & 251.6 & 236.5 & 413.1 & 25.82 \\
\hline
\end{tabular}

Table 2. Quantitative composition of the experimental diets.

\begin{tabular}{|c|c|c|c|c|}
\hline \multirow{2}{*}{ Ingredients } & \multicolumn{4}{|l|}{ Treatment } \\
\hline & Bean coproduct & Soybean meal & Sunflower meal & Cottonseed meal \\
\hline Bean coproduct, $\mathrm{g} \mathrm{kg}^{-1}$ as fed & 442.3 & - & - & - \\
\hline Soybean meal, $\mathrm{g} \mathrm{kg}^{-1}$ as fed & - & 230.8 & - & - \\
\hline Sunflower meal, $\mathrm{g} \mathrm{kg}^{-1}$ as fed & - & - & - & 269.3 \\
\hline Cottonseed meal, $\mathrm{g} \mathrm{kg}^{-1}$ as fed & - & - & 331.6 & - \\
\hline Corn bran, $\mathrm{g} \mathrm{kg}^{-1}$ as fed & 534.4 & 740.4 & 642.2 & 705.7 \\
\hline Urea, $\mathrm{g} \mathrm{kg}^{-1}$ as fed & 1.5 & 1.0 & 1.3 & 1.2 \\
\hline Calcium phosphate, $\mathrm{g} \mathrm{kg}^{-1}$ as fed & 7.8 & 10.6 & 10.3 & 4.6 \\
\hline Limestone, $\mathrm{g} \mathrm{kg}^{-1}$ as fed & 15.5 & 18.3 & 15.9 & 20.4 \\
\hline
\end{tabular}


The apparent digestibility coefficients of dry matter and other nutrients were obtained by the ratio between the intake of these nutrients and their fecal excretions, multiplied by 1000 . The excretion of nutrients was obtained by excreting fecal dry matter multiplied by the concentration of nutrients in the faeces.

The milk was weighed on the twelfth and fourteenth days of each experimental period, whereas the milk samples were collected on the fourth day of each period. Before the collection, the milk was homogenized and, immediately after it was stored in a container with preservative (Bronopol ${ }^{\circledR}$ ) at the proportion of $2 / 3$ during the morning milking and $1 / 3$ in the afternoon milking. The morning samples were placed under refrigeration, and at the end of the day, they were mixed with the afternoon samples. After collection, milk samples were sent to the laboratory where analyzed for fat, protein, lactose, total solids, dry extract defatted, somatic cell count, urea nitrogen, casein, and protein of casein.

The milk yield was corrected for $4 \%$ of fat, using the formula described in the NRC (1989): Milk yield corrected to $4 \%$ fat $=0.4 \times$ ( $\mathrm{kg}$ of milk) + $15 \mathrm{x}$ (kg of fat).

The following linear mixed statistical model was adopted (TEMPELMAN, 2004):

$Y_{i k l}=\mu+\alpha_{i}+c_{k}+\beta_{l}+\alpha \beta_{i l}+e_{i k l}$.

in which $Y_{i k l}$ is the observation related to the variable measured in the $\mathrm{k}$-th cow fed to the $\mathrm{i}$-th treatments during the 1-th period. The fixed effects are the mean $(\mu)$, the treatments $\left(\alpha_{i}\right)$, the periods for the two simultaneous balanced Latin squares $\left(\beta_{l}\right)$, and the treatment by period interaction $\left(\alpha \beta_{i l}\right)$. The random effects are cow $\left(c_{k}\right)$ and the usual error term $\left(e_{i k l}\right)$.

The statistical model was fitted using the PROC MIXED procedure of SAS (version 9; SAS Institute Inc., Cary, NC, USA) with restricted maximum likelihood (REML) as the estimation method. The repeated command was used with $c_{k}$ as subjects.

The variance-covariance matrix was modeled as variance components, compound symmetry, first order auto-regressive correlations, and as the unrestricted variance-covariance structure (LITTELL et al., 2006). The likelihood of the different variance-covariance structures was assessed by computing Akaike information criteria (AKAIKE, 1974) as suggested by Vieira et al. (2012). The comparison between treatments was done by the Tukey test at $5 \%$ of probability.

\section{RESULTS}

The adjustment of the variables using the different variance-covariance structures showed a predominance of variance components (VC), but each structure was selected as the most probable one at least once (Table 3). The unrestricted (UN) variance-covariance structure did not fit for all nutrient digestibility variables.

The treatment means were presented followed by amplitude of $95 \%$ confidence intervals divided by 2 , for the variables that had no effect was calculated the general mean. In relation to the intake, the treatments influenced only the intake of nutrients crude protein $(\mathrm{P}=0.019)$ and crude fat $(\mathrm{P}<0.001)$. Supplementation with soybean meal resulted in the highest intake of crude protein, while supplementation with bean coproduct resulted in the lowest intake of crude protein (Tables 3 and 4). Supplementation with sunflower meal caused the greatest intake of crude fat.

In relation to nutrient digestibility, treatments influenced DOM $(\mathrm{P}<0.001)$, DCP $(\mathrm{P}=$ $0.020)$ and, DNDF $(\mathrm{P}<0.001)$, cottonseed meal presented the worst digestibility in both variables (Tables 3 and 4). The interaction treatment $\mathrm{x}$ periods was significant for the variables DDM $(\mathrm{P}=0.018)$, and DNFC $(\mathrm{P}=0.031)$, in all periods the supplementation with soybean meal was presented the highest digestibility.

Milk production (MY) and production corrected to $4 \%$ fat (MY4) were influenced by the treatments, for MY the soybean meal together with the sunflower meal provided the highest yields, whereas for MY4 only the soybean meal was higher. Note that for both variables the bean coproduct was the worst supplement in productive terms (Table 5).

Regarding milk composition, the only variable that presented treatment effect was TS $(\mathrm{P}=$ 0.025), in which supplementation with soybean meal was higher than the others. The composition of the milk predominantly was not altered by the supplement, and the only exception, total solids (TS), followed the milk yield trend (MY and MY4), where soybean meal was better (Table 5). 
Table 3. $P$-values and variance-covariance matrix related to the measured variables.

\begin{tabular}{|c|c|c|c|c|}
\hline \multirow{2}{*}{ Variable } & \multicolumn{3}{|l|}{ P-values } & \multirow{2}{*}{$\begin{array}{l}\text { Variance-covariance } \\
\text { matrix }\end{array}$} \\
\hline & Treatment & Period & Treatment*Period & \\
\hline $\mathrm{W}$ & 0.483 & 0.003 & 0.083 & $\mathrm{CS}$ \\
\hline DMI & 0.791 & 0.962 & 0.749 & $\mathrm{VC}$ \\
\hline OMI & 0.750 & 0.961 & 0.772 & $\mathrm{VC}$ \\
\hline AshI & 0.314 & 0.944 & 0.438 & $\mathrm{VC}$ \\
\hline CPI & 0.019 & 0.967 & 0.917 & $\mathrm{VC}$ \\
\hline CFI & $<0.001$ & 0.978 & 0.541 & $\mathrm{VC}$ \\
\hline NDFI & 0.193 & 0.963 & 0.293 & $\mathrm{VC}$ \\
\hline TCI & 0.841 & 0.961 & 0.750 & $\mathrm{VC}$ \\
\hline NFCI & 0.700 & 0.913 & 0.976 & $\mathrm{VC}$ \\
\hline DDM & $<0.001$ & 0.883 & 0.018 & $\mathrm{AR}(1)$ \\
\hline DOM & $<0.001$ & 0.739 & 0.249 & $\mathrm{VC}$ \\
\hline DCP & 0.020 & 0.166 & 0.581 & $\mathrm{VC}$ \\
\hline DNDF & $<0.001$ & 0.007 & 0.057 & $\mathrm{VC}$ \\
\hline DNFC & 0.002 & 0.108 & 0.031 & $\mathrm{VC}$ \\
\hline MY & 0.010 & $<0.001$ & 0.103 & $\mathrm{VC}$ \\
\hline MY4 & 0.001 & $<0.001$ & 0.149 & $\mathrm{CS}$ \\
\hline Fat & 0.073 & 0.685 & 0.110 & $\mathrm{AR}(1)$ \\
\hline Prot & 0.626 & 0.375 & 0.914 & $\mathrm{CS}$ \\
\hline $\mathrm{Lac}$ & 0.927 & 0.005 & 0.915 & $\mathrm{CS}$ \\
\hline TS & 0.025 & 0.330 & 0.317 & $\mathrm{CS}$ \\
\hline DED & 0.847 & 0.586 & 0.926 & $\mathrm{CS}$ \\
\hline SCC & 0.767 & 0.510 & 0.462 & UN \\
\hline Un & 0.166 & 0.052 & 0.068 & $\mathrm{VC}$ \\
\hline Cas & 0.942 & 0.994 & 0.968 & $\mathrm{CS}$ \\
\hline PCas & 0.411 & 0.009 & 0.995 & $\mathrm{CS}$ \\
\hline
\end{tabular}

W - live weight, DMI - dry matter intake, OMI - organic matter intake, AshI - ash intake, CPI - crude protein intake, CFI - crude fat intake, NDFI - neutral detergent fiber intake, TCI - total carbohydrates intake, NFCI - non-fibrous carbohydrates intake, DDM digestibility of dry matter, DOM - digestibility of organic matter, DCP - digestibility of crude protein, DNDF - digestibility of neutral detergent fiber, DNFC - digestibility of non-fibrous carbohydrates, MY - milk yield, MY4 - milk yield corrected for $4 \%$ of fat, Prot protein in milk, Lac - lactose, TS - total solids, DED - dry extract defatted, SCC - somatic cell count, Un - urea nitrogen, , Cas - casein, and PCas - protein of casein; VC - variance components, CS - compound symmetry, AR(1) - first order auto-regressive correlations, and UN - unrestricted. 
Table 4. Intakes and digestibility of dry matter and nutrients in the function of the experimental diets.

\begin{tabular}{llllll}
\hline \multirow{2}{*}{ Variable } & Treatments & & & General \\
\cline { 2 - 5 } & Bean coproduct & Soybean meal & Sunflower meal & Cottonseed meal & \\
\hline DMI & $11.07 \pm 1.38$ & $11.72 \pm 1.38$ & $11.41 \pm 1.38$ & $10.84 \pm 1.38$ & $11.26 \pm 1.38$ \\
OMI & $10.22 \pm 1.28$ & $10.90 \pm 1.28$ & $10.69 \pm 1.28$ & $10.09 \pm 1.28$ & $10.48 \pm 1.28$ \\
AshI & $0.84 \pm 0.11$ & $0.81 \pm 0.11$ & $0.72 \pm 0.11$ & $0.75 \pm 0.11$ & $0.78 \pm 0.11$ \\
CPI & $1.24 \pm 0.18 \mathrm{~B}$ & $1.66 \pm 0.18 \mathrm{~A}$ & $1.43 \pm 0.18 \mathrm{AB}$ & $1.44 \pm 0.18 \mathrm{AB}$ & - \\
CFI & $0.14 \pm 0.02 \mathrm{~B}$ & $0.13 \pm 0.02 \mathrm{~B}$ & $0.19 \pm 0.02 \mathrm{~A}$ & $0.12 \pm 0.02 \mathrm{~B}$ & - \\
NDFI & $4.45 \pm 0.59$ & $4.31 \pm 0.59$ & $4.42 \pm 0.59$ & $3.67 \pm 0.59$ & $4.21 \pm 0.59$ \\
TCI & $8.85 \pm 1.09$ & $9.11 \pm 1.09$ & $9.07 \pm 1.09$ & $8.52 \pm 1.09$ & $8.89 \pm 1.09$ \\
NFCI & $4.96 \pm 0.68$ & $5.42 \pm 0.68$ & $5.20 \pm 0.68$ & $5.30 \pm 0.68$ & $5.22 \pm 0.68$ \\
DDM & $580.7 \pm 32.3 \mathrm{AB}$ & $654.4 \pm 32.3 \mathrm{~A}$ & $570.9 \pm 32.3 \mathrm{~B}$ & $545.1 \pm 33.3 \mathrm{~B}$ & - \\
DOM & $564.4 \pm 34.7 \mathrm{~A}$ & $566.4 \pm 34.7 \mathrm{~A}$ & $364.0 \pm 34.7 \mathrm{~B}$ & $234.6 \pm 38.8 \mathrm{C}$ & - \\
DCP & $621.5 \pm 50.4 \mathrm{AB}$ & $713.1 \pm 50.4 \mathrm{~A}$ & $626.3 \pm 50.4 \mathrm{AB}$ & $596.3 \pm 56.4 \mathrm{~B}$ & - \\
DNDF & $594.6 \pm 27.4 \mathrm{~B}$ & $652.7 \pm 27.4 \mathrm{~A}$ & $399.3 \pm 27.4 \mathrm{C}$ & $395.5 \pm 30.6 \mathrm{C}$ & - \\
DNFC & $672.6 \pm 27.2 \mathrm{~B}$ & $729.9 \pm 27.2 \mathrm{~A}$ & $730.3 \pm 27.2 \mathrm{~A}$ & $669.7 \pm 30.4 \mathrm{~B}$ & - \\
\hline DMI & &
\end{tabular}

DMI - dry matter intake $\left(\mathrm{kg} \mathrm{day}^{-1}\right)$, OMI - organic matter intake $\left(\mathrm{kg} \mathrm{day}^{-1}\right), \mathrm{AshI}$ - ash intake $\left(\mathrm{kg} \mathrm{day}^{-1}\right), \mathrm{CPI}$ - crude protein intake $(\mathrm{kg}$ day $\left.^{-1}\right)$, CFI - crude fat intake $\left(\mathrm{kg} \mathrm{day}^{-1}\right)$, NDFI - neutral detergent fiber intake $\left(\mathrm{kg} \mathrm{day}^{-1}\right)$, TCI - total carbohydrates intake $\left(\mathrm{kg} \mathrm{day}^{-1}\right)$, NFCI - non-fibrous carbohydrates intake $\left(\mathrm{kg} \mathrm{day}^{-1}\right)$, DDM - digestibility of dry matter $\left(\mathrm{g} \mathrm{kg}^{-1}\right)$, DOM - digestibility of organic matter $(\mathrm{g}$ $\left.\mathrm{kg}^{-1}\right)$, DCP - digestibility of crude protein $\left(\mathrm{g} \mathrm{kg}^{-1}\right)$, DNDF - digestibility of neutral detergent fiber $\left(\mathrm{g} \mathrm{kg}^{-1}\right)$, DNFC - digestibility of nonfibrous carbohydrates $\left(\mathrm{g} \mathrm{kg}^{-1}\right)$; Means in the same row followed by different letters differ according to the Tukey test $(\mathrm{P}<0.050)$. 
Table 5. Yield and composition of the milk in the function of the experimental diets.

\begin{tabular}{|c|c|c|c|c|c|}
\hline \multirow{2}{*}{ Variable } & \multicolumn{4}{|l|}{ Treatments } & \multirow{2}{*}{ General mear } \\
\hline & Bean coproduct & Soybean meal & Sunflower meal & Cottonseed meal & \\
\hline MY & $12.1 \pm 1.56 \mathrm{~B}$ & $15.9 \pm 1.56 \mathrm{~A}$ & $15.3 \pm 1.56 \mathrm{~A}$ & $15.0 \pm 1.56 \mathrm{AB}$ & - \\
\hline MY4 & $10.5 \pm 1.73 \mathrm{C}$ & $14.4 \pm 1.73 \mathrm{~A}$ & $12.1 \pm 1.73 \mathrm{BC}$ & $12.7 \pm 1.73 \mathrm{AB}$ & - \\
\hline Fat & $27.5 \pm 4.47$ & $29.0 \pm 4.47$ & $22.8 \pm 4.47$ & $25.0 \pm 4.47$ & $26.1 \pm 4.47$ \\
\hline Prot & $31.5 \pm 3.13$ & $32.2 \pm 3.13$ & $31.6 \pm 3.13$ & $31.4 \pm 3.13$ & $31.7 \pm 3.13$ \\
\hline $\mathrm{Lac}$ & $45.1 \pm 2.50$ & $45.3 \pm 2.50$ & $45.4 \pm 2.50$ & $45.6 \pm 2.50$ & $45.4 \pm 2.50$ \\
\hline TS & $113.3 \pm 7.29 \mathrm{AB}$ & $115.7 \pm 7.29 \mathrm{~A}$ & $108.9 \pm 7.29 \mathrm{~B}$ & 111.2 $\pm 7.29 \mathrm{AB}$ & - \\
\hline DED & $85.7 \pm 3.94$ & $86.7 \pm 3.94$ & $86.1 \pm 3.94$ & $86.3 \pm 3.94$ & $86.2 \pm 3.94$ \\
\hline SCC & $88.1 \pm 15.96$ & $127.1 \pm 127.19$ & $124.4 \pm 37.12$ & $188.5 \pm 138.97$ & $132.0 \pm 154.81$ \\
\hline Un & $16.8 \pm 1.72$ & $18.5 \pm 1.72$ & $17.6 \pm 1.72$ & $15.9 \pm 1.72$ & $17.2 \pm 1.72$ \\
\hline Cas & $23.94 \pm 2.80$ & $24.30 \pm 2.80$ & $24.1 \pm 2.80$ & $24.2 \pm 2.80$ & $24.1 \pm 2.80$ \\
\hline PCas & $759.5 \pm 18.30$ & $753.98 \pm 18.30$ & $761.51 \pm 18.30$ & $767.81 \pm 18.30$ & $760.70 \pm 18.30$ \\
\hline
\end{tabular}

MY - Milk yield $\left(\mathrm{kg} \mathrm{day}^{-1}\right)$, MY4 - Milk yield corrected for $4 \%$ fat $\left(\mathrm{kg} \mathrm{day}^{-1}\right)$, Fat $\left(\mathrm{g} \mathrm{kg}^{-1}\right.$ milk), Prot - Protein $\left(\mathrm{g} \mathrm{kg}^{-1}\right.$ milk), Lac - Lactose $\left(\mathrm{g} \mathrm{kg}^{-1}\right.$ milk), TS - Total solids ( $\mathrm{g} \mathrm{kg}^{-1}$ milk), DED - Dry extract defatted $\left(\mathrm{g} \mathrm{kg}^{-1}\right.$ milk), SCC - Somatic cell count $\left(\mathrm{x} 1000 \mathrm{~mL}^{-1}\right)$, Un - Urea nitrogen $\left(\mathrm{mg} \mathrm{dL}^{-1}\right)$, Cas - Casein $\left(\mathrm{g} \mathrm{kg}^{-1}\right)$, Pcas - Protein of casein $\left(\mathrm{g} \mathrm{kg}^{-1}\right.$ of protein).

Means in the same row followed by different letters differ according to the Tukey test $(\mathrm{P}<0.050)$. 


\section{DISCUSSION}

The investigation of better variancecovariance (Table 3) structures, based on the Akaike criterion corrected, reveals that the errors are correlated in some cases, this indicates that assuming the independence of the errors in simultaneous Latin square delineations can be incur a mistaken analysis of data (AKAIKE, 1974; JARDIM et al. 2013; VIEIRA et al. 2012).

The superiority of the soybean meal and sunflower meal for CPI and CFI, respectively (Table 4), follows the same pattern in relation to the chemical composition of these foods (table 1), but this behavior did not extend to the other variables of the intake that stood out in terms of chemical composition, as in the case of sunflower meal for NDF content and bean coproduct for NFC content (Tables 1 and 4).

Pina et al. (2006) evaluated nutrient intake by cows fed diets containing different protein sources, including soybean meal and cottonseed meal, and did not observe differences in dry matter and organic matter intake, a behavior observed in the present study. Already Magalhães et al. (2008) reported that beans have a high time of colonization of their fibrous portion (lag time) which delays fiber degradation, resulting in a lower flow in the gastrointestinal tract of the animals, which may affect intake. This behavior may be barely perceptible due to the low fiber content of the treatment with bean coproduct, but in this case the fiber quality is as important as the quantity.

The absence of a significant effect for most intake variables, especially dry matter, organic matter and fiber (Table 4) indicates the possibility of using any of the feeds with the objective of supplementation, but the superiority of soybean meal in relation to to crude protein intake (CPI), which is a nutrient deficient in pastures mainly in the winter, and its superior performance in terms of digestibility makes it the most suitable for supplementation.

Conrad et al. (1964) have shown that the physical and physiological factors that regulate food intake are altered by the increased dry matter digestibility of the diet and that for diets below 660 $\mathrm{g} / \mathrm{kg}$ of apparent digestibility, physical factors are determinant of intake. This report may explain the lack of effect for most of the intake variables evaluated in the present study, since they presented dry matter digestibility values lower than the reference cited above (Table 4).
The performance obtained by the bean coproduct for DDM, DOM and DCP credence as a potential low cost alternative to soybean meal, mainly in animal categories of lower nutritional requirement and because it is an abundant residue in regions producing this food. The cottonseed meal was the supplement that presented the worst results in terms of digestibility, a behavior also observed by Pina et al. (2006), and since the main intake variables did not present a significant effect, it can be inferred that among the supplements evaluated, this was the one least able to replace soybean meal (Table 4). Soybean meal was the one that presented the best results in terms of digestibility, regardless of the evaluated nutrient.

Regarding milk production, the same soybean meal superiority trend was observed for both MY and MY4. On the other hand, the bean coproduct showed good results in terms of intake and digestibility, as previously discussed, showing the worst values for yield variables (Table 5), which may be due to poor protein quality and the presence of anti-nutritional factors of the bean coproduct, demonstrating that caution should be exercised in the use of this supplement, mainly in category more demanding animals such as dairy cows.

Contradictory results are reported in the literature regarding the production of dairy cows supplemented with different protein sources such studies reveal since no significant effect (BERNARD, 1997; PINA et al, 2006; MENA et al, 2001; MENA et al, 2004.) to the linear decrease of milk production with the inclusion of bean residues (MAGALHÃES et al., 2008).

\section{CONCLUSIONS}

The soybean meal and the cotton meal stood out in allowing better milk yields with good composition.

The bean coproduct stands out as a low-cost protein source but should not fully replace soybean meal, especially in animal categories of higher nutritional requirement.

\section{ACKNOWLEDGEMENTS}

R. P. Araujo thanks the Instituto Federal do Tocantins (IFTO) for the support to carry out the experimente. R. S. Gomes thanks the post-doctoral fellowships provided by Fundação de Amparo à Pesquisa do Estado do Rio de Janeiro (FAPERJ) and Coordenação de Aperfeiçoamento de Pessoal de Nível Superior (CAPES). 
RESUMO: Objetivou-se com este estudo avaliar a suplementação de vacas leiteiras com diferentes fontes proteicas em relação ao consumo, digestibilidade, produção e composição química do leite. Para tanto, utilizou-se oito vacas mestiças (Holandês x Gir), distribuídas em dois quadrados latinos (4x4) simultâneos. Os tratamentos utilizados foram: coproduto do feijão, farelo de soja, farelo de girassol e farelo de algodão. Foram testadas quatro estruturas de variância-covariância por meio do critério de Akaike corrigido para determinar o melhor ajuste aos dados, e posteriormente foram submetidas à análise de variância, sendo as médias dos tratamentos comparadas pelo teste de Tukey, a 5\% de probabilidade. Apenas os consumos de proteína bruta e gordura bruta foram influenciados pelos tratamentos, já em relação a digestibilidade, independente do nutriente avaliado o farelo de soja foi o melhor tratamento ou esteve entre os melhores, comportamento este observado também para a produção de leite. Com isso, concluiu-se que dentre os suplementos utilizados o farelo de soja é a melhor fonte proteica, e o coproduto de feijão se destaca como uma fonte proteica de baixo custo, mas que deve substituir integralmente o farelo de soja, principalmente em categorias animais com alta exigência nutricional.

PALAVRAS-CHAVE: Consumo. Coproduto do feijão. Digestibilidade. Produção de leite.

\section{REFERENCES}

AKAIKE, H. A new look at the statistical model identification. IEEE Transactions on Automatic Control, Notre Dame, v. 19, p. 716-723, 1974. http://dx.doi.org/10.1109/TAC.1974.1100705

AOAC - ASSOCIATION OF OFFICIAL ANALYTICAL CHEMISTRY. Official methods of analysis. 15th ed. Washington: AOAC International, 1990. 1298 p.

BERNARD, J. K. Milk production and composition responses to source of protein supplement in diets containing wheat middlings. Journal of Dairy Science, Champaign, v. 80, p. 938-942, 1997. https://doi.org/10.3168/jds.S0022-0302(97)76017-X

CARVALHO JÚNIOR, J. N.; PIRES, A. J. V.; VELOSO, C. M.; SILVA, F. F.; REIS, R. A.; CARVALHO, G. G. P. Digestibilidade aparente da dieta com capim-elefante ensilado com diferentes aditivos. Arquivos Brasileiros Medicina Veterinária e Zootecnia, Belo Horizonte, v. 62, p. 889-897, 2010. http://dx.doi.org/10.1590/S0102-09352010000400019

COCHRAN, R. C.; ADAMS, D. C.; WALLACE, J. D. AND GALYEAN, M. L. Predicting digestibility of different diets with internal markers: evaluation of four potential markers. Journal of Animal Science, Champaign, v. 63, p. 1476-1483, 1986. https://doi.org/10.2527/jas1986.6351476x

CONRAD, H. R.; PRATT, A. D.; HIBBS, J. W. Regulation of feed intake in dairy cows. 1. Change in importance of physical and physiological factors with increasing digestibility. Journal of Dairy Science, Champaign, v. 47, p. 54-62, 1964. https://doi.org/10.3168/jds.S0022-0302(64)88581-7

GOES, R. H. T. B.; KLEIN, K.W.; MATINHAGO, L.H.; OLIVEIRA, E; R.; BRABES, K. C. S.; GRESSLER, M. G. M.; YOSHIRAHA, M. M.; OLIVEIRA, R. T.; SANTOS, E. M. L. Common beans (Phaseolus vulgaris L.) in the rations for cattle in feedlot. Agricultural Sciences, Hubei Province, v. 4, p. 774-780, 2013. doi: 10.4236/as.2013.412106

JARDIM, J. G.; VIEIRA, R. A. M.; FERNANDES, A. M.; ARAUJO, R. P.; GLORIA, L. S.; ROHEM JÚNIOR, N. M. ROCHA, N. S.; ABREU, M. L. C. Application of a nonlinear optimization tool to balance diets with constant metabolizability. Livestock Science, Amsterdam, v. 158, p. 106-117, 2013. https://doi.org/10.1016/j.livsci.2013.09.012

LEÃO, M. I. Metodologias de coletas de digestas omasal e abomasal em novilhos submetidos a três níveis de ingestão: consumo, digestibilidade e produção microbiana. 2002. 57 f. Tese (Doutorado em Ciência Animal) - Curso de Pós-graduação em Ciência Animal, Universidade Federal de Belo Horizonte, Belo Horizonte, 2002. 
LITTELL, R. C.; MILLIKEN, G. A.; STROUP, W. W.; WOLFINGER, R. D.; SCHABENBERGER, O. SAS ${ }^{\circledR}$ for mixed models. Cary: SAS Institute Inc., 2006. 828 p.

MAGALHÃES, A. L. R.; ZORZI, K.; QUEIROZ, A. C.; MELLO, R.; DETMANN, E.; PEREIRA, J. C. Consumo e digestibilidade aparente total dos nutrientes, produção e composição do leite de vacas alimentadas com dietas contendo diferentes fontes de proteína. Revista Brasileira de Zootecnia, Viçosa, v. 37, p. 529-537, 2006. http://dx.doi.org/10.1590/S1516-35982006000500037

MENA, H.; SANTOS, J. E. P.; HUBER, J. T.; SIMAS, J. M.; TARAZON, M.; CALHOUN, M. C. THE effects of feeding varying amounts of gossypol from whole cottonseed and cottonseed meal in lactating dairy cows. Journal of Dairy Science, Champaign, v. 84, p. 2231-2239, 2001. https://doi.org/10.3168/jds.S00220302(01)74670-X

MENA, H.; SANTOS, J. E. P.; HUBER, J. T.; TARAZON, M.; CALHOUN, M. C. The effects of varying gossypol intake from whole cottonseed and cottonseed meal on lactation and blood parameters in lactating dairy cows. Journal of Dairy Science, Champaign, v. 87, p. 2506-2518, 2004.

https://doi.org/10.3168/jds.S0022-0302(04)73375-5

NOCEK, J. E. In situ and other methods to estimate ruminal protein and energy digestibility: a review. In: TEIXEIRA, J. C (Ed.). Digestibilidade em ruminantes. Lavras: FAEPE, Lavras,1997. p. 197-240.

NRC - National Research Council. Nutrient requeriments of dairy cattle. 6th ed. Washington: National Academic Press, 1989. 158 p.

NRC - National Research Council. Nutrient requirements of dairy cattle. 7th ed. Washington: National Academic Press, 2001. 381p.

NUNES, I. J. Cálculo e avaliação de rações e suplementos. Belo Horizonte: FEP-MVZ, 1998. 185 p.

PEREIRA, J. C. Vacas leiteiras - aspectos práticos da alimentação. Viçosa: Editora Aprenda Fácil, 2000. $198 \mathrm{p}$.

PINA, D. S.; VALADARES FILHO, S. C.; VALADARES, R. F. D.; CAMPOS, J. M.S.; DETMANN, E.; MARCONDES, M. I.; OLIVEIRA, A. S.; TEIXEIRA, R. M. A. Consumo e digestibilidade aparente total dos nutrientes, produção e composição do leite de vacas alimentadas com dietas contendo diferentes fontes de proteína. Revista Brasileira de Zootecnia, Viçosa, v. 35, p. 1543-1551, 2008.

http://dx.doi.org/10.1590/S1516-35982006000500037

SHARASIA, P. L., GARG, M. R. \& BHANDERI, B. M. Pulses and their by-products as animal feed. Rome: FAO, 2017. 204 p.

SILVA, J. F. C.; LEÃO, M. I. Fundamentos de nutrição dos ruminantes. Piracicaba: Livroceres, 1979. 384 p.

SNIFFEN, C. J.; O'CONNOR, J. D.; VAN SOEST, P. J.; FOX, D. G.; RUSSEL, J. B. A net carbohydrate and protein system for evaluation cattle diets. II. Carbohydrate and protein availability. Journal Animal Science, Champaign, v. 70, p. 3562-3577, 1992. https://doi.org/10.2527/1992.70113562x

SOLLENGERGER, L. E.; CHERNEY, D. J. R. Evaluating forage production and quality. In: BARNES, R. F.; NELSON, C. F.; MILLER D. (Ed.). The science grassland agriculture. Iowa city: Iowa State University Press, 1995. p. 97-110.

TEMPELMAN, R. J. Experimental design and statistical methods for classical and bioequivalence hypothesis testing with na application to dairy nutrition studies. Journal of Animal Science, Champaign, v. 82, p. $162-$ 172, 2004. https://doi.org/10.2527/2004.8213_supplE162x 
THIEX, N. J.; ANDERSON, S.; GILDEMEISTER, B. Crude fat, hexanes extraction, in feed, cereal grain, and forage (Randall/soxtec/submersion method): collaborative study. Journal of AOAC International, Rockville, v. 86, p. 899-908, 2003.

THIEX, N. J.; MANSON, H.; ANDERSON, S.; PERSSON, J. A. Determination of crude protein in animal feed, forage, grain, and oilseeds by using block digestion with a copper catalyst and steam distillation into boric acid: collaborative study. Journal of AOAC International, Rockville, v. 85, p. 309-317, 2002.

VAN SOEST, P. J.; ROBERTSON, J. B; LEWIS, B. A. Methods for dietary fiber, neutral detergent fiber, and nonstarch polysaccharides in relation to animal nutrition. Journal of Dairy Science, Champaign, v. 74, p. 3583-3597, 1991. https://doi.org/10.3168/jds.S0022-0302(91)78551-2

VIEIRA, R. A. M.; CAMPOS, P. R. S. S.; SILVA, J. F. C.; TEDESCHI, L. O.; TAMY, W. P. Heterogeneity of the digestible insoluble fiber of selected forages in situ. Animal Feed Science and Technology, Amsterdam, v. 171, p. 154-166, 2012. https://doi.org/10.1016/j.anifeedsci.2011.11.001

WILLIANS, C. H.; DAVID, D. J.; ILSMAA, O. The determination of chromic oxide in feces samples by atomic absorption spectrophotometers. Journal Agriculture Science, Cambridge, v. 59, p. 381-385, 1962. https://doi.org/10.1017/S002185960001546X 